\title{
Survey on Chlamydophila psittaci in captive ramphastids in São Paulo State, Brazil
}

\author{
Pesquisa de Chlamydophila psittaci em ranfastídeos cativos no Estado de São Paulo, Brasil
}

\author{
Tânia de Freitas Raso ${ }^{{ }^{*}}$ Vivian Lindmayer Ferreira' ${ }^{\mathrm{I}}$ Rodrigo Hidalgo Friciello Teixeira ${ }^{\mathrm{II}}$ \\ Aramis Augusto Pinto ${ }^{\mathrm{III}}$
}

\section{ABSTRACT}

Chlamydophila psittaci (C. psittaci) has been detected in 460 avian species, among them the most frequent are the Psittaciformes, Columbiformes, Anseriformes and raptors. In Brazil, the main avian species recognized as healthy carriers belong to the order Psittaciformes and Columbiformes, but very few studies have been done in other bird families. Reports of the occurrence of this disease in the clinical form are rare in the Ramphastids; consequently, they are not commonly evaluated for this agent. The present study reports the investigation of $\boldsymbol{C}$. psittaci in 25 captive ramphastids from a zoological park in São Paulo State, Brazil. Swabs samples from the cloaca were submitted to semi-nested polymerase chain reaction (semi-nested PCR) for direct detection of the microorganism. Additionally, blood samples obtained from these birds were submitted to the Complement Fixation Test (CFT) for detection of antibodies anti-C. psittaci. The presence of C. psittaci was not detected in the cloacal swab samples tested by the PCR. Nevertheless, 16\% (4/25) of the bird's sera were positive by the CFT. Among the species with positive results, there are the saffron toucanet (Pteroglossus bailloni) and blacknecked-aracari (Pteroglossus aracari), two species with no descriptions of the survey of $\mathrm{C}$. psittaci published in the literature. Intermittent elimination of $\boldsymbol{C}$. psittaci is a feature of chronically infected birds; however the absence of a positiveantigen sample did not guarantee that the bird is Chlamydophila-free. The serological results obtained show that the ramphastids tested were previously exposed to the pathogen and developed immune response, but showed no clinical signs of the disease and didn't eliminate regularly the organism in their feces in the moment of the sample collection.

Key words: Aracaris, Chlamydiosis, Chlamydophila psittaci, Ramphastids, Toucans.

\section{RESUMO}

Chlamydophila psittaci (C. psittaci) tem sido detectada em 460 espécies aviárias, dentre elas, as mais frequentes são os Psitaciformes, Columbiformes, Anseriformes e Falconifomes. No Brasil, as principais espécies reconhecidas como portadoras pertencem às Ordens Columbiformes e Psitaciformes, porém poucas pesquisas foram realizadas em aves de outras famílias. Em ranfastídeos, são raros os relatos da ocorrência da forma clínica dessa doença, consequentemente, não é um patógeno comumente investigado. O presente estudo relata a investigação de C. psittaci em 25 ranfastídeos cativos em um parque zoológico de São Paulo. Amostras de suabes colhidas da cloaca foram submetidas à reação em cadeia pela polimerase (PCR) para detecção direta do microrganismo. Adicionalmente, amostras de soro sanguíneo obtidas dessas aves foram submetidas à reação de Fixação do Complemento (RFC) para detecção dos anticorpos anti-C. psittaci. Não foi detectada a presença de C. psittaci em nenhuma das amostras de suabe cloacal testadas pela PCR. No entanto, $16 \%$ (4/25) das amostras de soros foram positivas pela RFC. Entre as espécies com resultados positivos, estão o araçari-banana (Pteroglossus bailloni) e o araçari-de-bicobranco (Pteroglossus aracari), ambas sem publicações prévias relacionadas à $\boldsymbol{C}$. psittaci. A eliminação intermitente de $\boldsymbol{C}$. psittaci é uma característica de aves cronicamente infectadas, porém um resultado negativo para pesquisa do agente não significa necessariamente que a ave esteja livre do patógeno. Os resultados sorológicos obtidos demonstram que algumas aves tiveram contato prévio com o microrganismo e desenvolveram resposta imune, porém não apresentavam sinais clínicos evidentes de doença e não eliminavam o agente etiológico no momento da colheita da amostra.

Palavras-chave: Araçari, Clamidiose, Chlamydophila psittaci, Ranfastídeos, Tucanos.

IDepartamento de Patologia, Faculdade de Medicina Veterinária e Zootecnia (FMVZ), Universidade de São Paulo (USP), Av. Prof. Dr. Orlando Marques de Paiva, 87, Cidade Universitária, 05508-270, São Paulo, SP, Brasil. E-mail: tfraso@usp.br.*Autor para correspondência.

IIParque Zoológico Municipal Quinzinho de Barros, Sorocaba, SP, Brasil.

IIIDepartamento de Patologia Veterinária, Faculdade de Ciências Agrárias e Veterinárias (FCAV), Universidade Estadual Paulista

Júlio de Mesquita Filho (UNESP), Jaboticabal, SP, Brasil. 


\section{INTRODUCTION}

The Ramphastidae family, order Piciformes, comprising toucans and aracaris, are indigenous to South America, ranging from southern Mexico to northern Argentina. In Brazil, it occurs in all biomes, but the greatest diversity of species is located in the Amazon rainforest. Due to the popularity and beauty of these birds, some representatives of this family are relatively common in zoos. They have been successfully managed in captivity only during the past 50 years and reports of infectious diseases in ramphastids are still scarce (CORNELISSEN \& RITCHIE, 1994; CUBAS, 2001; JENNINGS, 2001).

Most bacterial infections in toucans are isolated in the upper respiratory or gastrointestinal systems. As with other avian species, most potentially pathogenic bacteria are Gram-negative organisms (WORELL, 2009). A Gram-negative bacterium still poorly studied in the Ramphastidae family is the Chlamydophila psittaci (CUBAS, 2001). Chlamydial organisms are nonmotile, obligate, intracellular, parasitic agents (SPEER, 1999). Transmission of $\boldsymbol{C}$. psittaci among avian species primarily occurs from one infected bird to another susceptible bird in close proximity. The agent is excreted in feces and nasal discharges. Fecal shedding can be activated through stress caused by nutritional deficiencies, prolonged transport, overcrowding, chilling, breeding, egg laying, and handling. Bacterial excretion periods during natural infection can vary depending on infection dose, host immune status and virulence of the strain (HARKINEZHAD, et al. 2009). Currently there are 8 serovars and 9 genotypes described and the main birds affected are psittacine, pigeons and doves (NASPHV, 2010).

Isolation of Chlamydophila or serologic evidence of exposure has been reported in many species of wild birds, but infection is often unapparent (ANDERSEN \& FRANSON, 2007). In general, the infected birds, even without showing clinical signs of the disease, eliminate the microorganism in the excreta, intermittently, for long periods of time. Consequently, contaminating the environment and spreading the agent for other birds or humans. Thus, chlamydiosis is considered one of the most important zoonosis transmitted by wild birds. Despite the fact that the Psittaciformes, Columbiformes and turkeys, are the main sources of human diseases, it should be emphasized that $C$. psittaci has been detected in more than 460 species of birds (KALETA \& TADAY, 2003). A few studies have already related $\boldsymbol{C}$. psittaci affecting some species of ramphastids (KALETA \& TADAY, 2003; LIJIMA et al., 2009). Nevertheless, further investigation of this agent in toucans and aracaris should be performed to determine the clinical importance of chlamydiosis in these avian species.

Since descriptions of infectious diseases in toucans and aracaris are lacking in veterinary literature, the proposal of this case report is to describe serological findings associated with the detection of C. psittaci in ramphastids and contributes to the understanding of the epidemiology of this disease. Then, the present study reports the investigation of $\boldsymbol{C}$. psittaci in 25 captive ramphastids from a zoological park in São Paulo state, Brazil.

\section{MATERIAL AND METHODS}

Cloacal swab and blood samples were collected from the entire loft of ramphastids (25 birds) from one Zoo in São Paulo state, Brazil. The loft was composed of eight species of ramphastids: seven tocotoucans (Ramphastos toco), four red-breasted toucans (Ramphastos dicolorus), four red-billed toucans (Ramphastos tucanus), four spot-billed toucanets (Selenidera maculirostris), three black-necked aracaris (Pteroglossus aracari), one saffron toucanet (Pteroglossus bailloni), one channel-billed toucan (Ramphastos vitellinus) and one chestnut-eared aracari (Pteroglossus castanotis).

Serum samples were submitted to complement fixation test (CFT) according to literature (RASO et al. 2006). Positive and negative serum controls were used. All serum samples were titrated in serial two-fold dilutions up to $1: 1,024$. Positive samples showed lysis greater than $50 \%$ at serum dilutions $1: 16$ or higher, in the presence of $2 \mathrm{U}$ complement (titer $\geq 16$ ).

DNA extraction from cloacal swab samples were performed by using the GFX Genomic Blood DNA Purification Kit (GE Healthcare, USA), according to the manufacturer's protocol. Semi-nested PCR was performed by using primers targeting a conserved region of the MOMP gene from Chlamydiaceae (RASO et al. 2006). Primers A(5'CAGGATATCTTGTCTGGCTTTAA3') and B (5'GCAAGGATCGCAAGGATC3') produced a 260-bp fragment in the PCR, whereas primers B (5'GCAAGGATCGCAAGGATC3') and C (5'TTAGAGGTGAGTATGAAAAAACTC3') amplified a 165-bp fragment in the semi-nested PCR. Amplification reactions contained $5 \mu \mathrm{L}$ of the DNA template, $1 \mathrm{x}$ enzyme reaction buffer, $0.2 \mathrm{mM}$ of dNTPs, $0.2 \mu \mathrm{M}$ of each primer, 1.25U of DNA polymerase (Biotools, Spain) and sterile water to a final volume of $25 \mu \mathrm{L}$. PCR cycling conditions were $10 \mathrm{~min}$ at $94^{\circ} \mathrm{C} ; 34$ cycles at $94^{\circ} \mathrm{C}$ for $1 \mathrm{~min}, 54^{\circ} \mathrm{C}$ for $1 \mathrm{~min}$ and $72^{\circ} \mathrm{C}$ for $1 \mathrm{~min}$; and a final extension at $72^{\circ} \mathrm{C}$ for $4 \mathrm{~min}$. The semi-nested PCR 
reaction was similar, except that $2 \mu \mathrm{L}$ of the amplified product which was added and annealing performed at $52^{\circ} \mathrm{C}$ for $1 \mathrm{~min}$. Positive and negative control samples were included in each run. PCR and semi-nested PCR products were analyzed by electrophoresis in $1.5 \%$ agarose gels stained with ethidium bromide $\left(0.5 \mu \mathrm{g} \mathrm{mL}^{-1}\right)$ and visualized under ultraviolet light.

\section{RESULTS}

All the ramphastids studied $(n=25)$ showed negative results in the semi-nested PCR, however, $16 \%$ of the birds $(n=4)$ were positive in the CFT. Antibodies anti - C. psittaci were detected in four of the eight studied species: Pteroglossus bailloni (1/1; titers of 1:16), Ramphastos dicolorus (1/4; titers of 1:32), Ramphastos toco (1/7; titers of 1:16), and Pteroglossus aracari (1/3; titers of 1:32). All birds showed no clinical signs of disease.

\section{DISCUSSION}

Currently it is known, that a large number of bird species have already been naturally infected with C. psittaci. From the reported number of infections in wild bird species, it can be assumed that probably all wild birds are susceptible to chlamydiosis (ANDERSEN \& FRANSON, 2007). A review published in 2003 showed the avian species that had been positive for Chlamydophila spp. by isolation of the organism, detection of antigen or antibodies (KALETA \& TADAY, 2003). A total of 460 free-living or pet bird species in 30 orders were Chlamydophila-positive; the order Psittaciformes contains by far the most positive birds. Probably, this high incidence reflects the frequency of testing, and psittacines' popularity as pets. On the other hand, in the Piciformes order reports of the occurrence of this disease are still scarce.

In this study the birds showed negative results in the semi-nested PCR. Nevertheless, this information is different from some reports found in literature, where Chlamydophila was detected in $\boldsymbol{R}$. ambiguous swainsonii and $\boldsymbol{R}$. vitellinus by PCR (KALETA \& TADAY, 2003; LIJIMA et al., 2009). This bacterium has also been detected in the species $\boldsymbol{R}$. toco and $\boldsymbol{R}$. sulfuratus by the smears and stamp technique (KALETA \& TADAY, 2003).

Nucleic acid amplification sometimes may reflect only a carrier status, and therefore serology can be helpful to confirm a clinical diagnosis of chlamydiosis (VANROMPAY, 2009). A positive serologic test result is evidence that the bird was infected by Chlamydiaceae at some point; on the other hand low titers doesn't confirm that the bird has a current active infection. In the present study, 4 (16\%) birds showed positive results by the complement fixation test. Despite the limited data in the literature, antibodies anti - C. psittaci were also detected trough this technique in an ariel-toucan (Ramphastos ariel) (KALETA\& TADAY, 2003).

It has been repeatedly shown that results of antigen detection do not always match with serological data, as observed in this study. Since seroconversion followed by natural exposure is probable, any sensitive antibody assay will detect infected birds (KALETA\& TADAY, 2003). The positive serological results (titers 16 and 32) obtained in this study show that some of these birds were infected by C. psittaci and developed humoral immune response, but had no current infection with evident clinical signs of disease and did not eliminate the causative agent in the moment of the sample collection.

The results obtained in the present study contribute to the documentation of an infectious agent in the Ramphastidae family, especially due to the fact that the species Pteroglossus bailloni and Pteroglossus aracari were not related so far with $\boldsymbol{C}$. psittaci in the veterinary literature. In addition, this issue is a public health concern since $\boldsymbol{C}$. psittaci is the cause of psittacosis in humans. Despite the fact that pigeons and psittacine are considered the main sources of human infection (ANDERSEN \& FRANSON, 2007; MAGNINO et al. 2009), other avian species may have an important role in the transmission of this zoonosis. In this case, the birds did not have clinical signs of the disease and were not eliminating the microorganism at the time of collection; however, birds positive for $\boldsymbol{C}$. psittaci may act as potential disseminators and possibly infect human beings. In Kobe, Japan, a psittacosis outbreak due to $\boldsymbol{C}$. psittaci at an avian exhibition was reported and a staff member of the establishment became ill (LIJIMA et al., 2009). Major outer membrane protein DNA sequence of Chlamydia in the patient's bronchoalveolar lavage fluid was identical to that derived from a channel-billed toucan (Ramphastos vitellinus) kept in a closed aviary.

The current study was carried out in a zoo. In zoos the main susceptible human population is composed of zoo workers, veterinarians, biologists, animal scientists, veterinary and biology students and animal keepers since most human infection occurs through inhalation of infectious aerosols. Infectious aerosols can be readily created while handling birds or working in confined areas where dried birds droppings are present (ANDERSEN \& FRANSON, 2007). 
A research performed in 20 Brazilian zoos indicated the occurrence of infection and previous contact of Brazilian zoo workers with C. psittaci (RASO et al., 2010). Individuals working with wild birds should be mindful about the zoonotic potential of chlamydiosis and should take reasonable biosafety precautions. When cleaning cages or handling infected birds, caretakers should wear protective clothing, which includes gloves, eyewear and masks (NASPHV, 2010). In the present study the zoo's birds were kept in an aviary and staff members were trained accordingly, using appropriate protective attire when handling birds. In this zoo avian species had no contact to visitors. Nevertheless, responsible for zoos with walks through aviaries and/or birds shows, putting visitors and birds into direct contact, should be aware of any diseases with zoonotic potential.

\section{CONCLUSION}

Despite the fact that Psitaciformes and Columbiformes are the main orders related to $\boldsymbol{C}$. psittaci, the present study show that other avian species may also be important in the ecoepidemiology of this pathogen, such as the ramphastids. Furthermore, two species (Pteroglossus bailloni and Pteroglossus aracari) had no previously report of $\boldsymbol{C}$. psittaci in the literature. Although the birds showed evidence of infection, others surveys of $\boldsymbol{C}$. psittaci in ramphastids should be performed in order to determinate the importance of the clinical form of chlamydiosis in this group.

\section{ACKNOWLEDGEMENTS}

The authors are grateful to the Zoo for the support the publication of these results.

\section{REFERENCES}

ANDERSEN, A.A.; FRANSON, J.C. Avian Clamydiosis. In: THOMAS, N.J. et al. Infectious diseases of wild birds. Ames: Iowa Blackwell Publishing, 2007. Cap.15, p.303-316.

CORNELISSEN, H.; RITCHIE, B.W. Ramphastidae. In: RITCHIE, B.W. ET AL. Avian medicine: principles and application. Lake Worth: Wingers, 1994. Cap.47, p.12761283.

CUBAS, Z.S. Medicine - family Rhamphastidae (toucans). In: FOWLER, M.E.; CUBAS, Z.S. Biology, medicine and surgery of south american wild animals. Ames: Iowa State University, 2001. Cap.19, p.188-199.

CUBAS, Z.S. Piciformes (Tucano, Araçari, Pica-Pau). In: CUBAS, Z.S. et al. Tratado de animais selvagens: medicina veterinária. São Paulo: Roca, 2007. Cap. 15, p.210-221.
HARKINEZHAD, T.et al. Chlamydophila psittaci infections in birds: a review with emphasis on zoonotic consequences. Veterinary Microbiology, v.135, p.68-77, 2009. Disponível em: <http:// www.ncbi.nlm.nih.gov/pubmed?term=Chlamydophila\%20psittaci $\% 20 \mathrm{i}$ nfections $\% 20$ in $\% 20$ birds $\% 3$ A \% 20 A \% 20 review $\%$ 20with $\% 20$ emphasis $\% 20$ on $\% 20$ zoonotic $\% 20$ consequences $>$. Acesso em: 13 mar. 2011. doi: doi:10.1016/j.vetmic.2008.09.046.

JENNINGS, J. Captive management - family Rhamphastidae (toucans). In: FOWLER, M.E.; CUBAS, Z.S. Biology, medicine and surgery of south american wild animals. Ames: Iowa State University, 2001. Cap.19, p.186-188.

KALETA, E.F.: TADAY, E.M.A. Avian host range of Chlamydophila spp. based on isolation, antigen detection and serology. Avian Pathology, v.32, p.435-61, 2003. Disponível em: <http:// w w w. i n f o r m a w o r l d. c o m / s m p p / content $\sim \mathrm{db}=\mathrm{all} \sim$ content $=\mathrm{a} 713991421>$. Acesso em: 20 dez. 2009. doi: 10.1080/03079450310001593613.

LIJIMA, Y. et al. Psittacosis outbreak at an avian exhibition. Kansenshogaku Zasshi, v.83, n.5, p.500-505, 2009. Disponível em: <http://www.ncbi.nlm.nih.gov/pubmed/ 19860250>. Acesso em: 12 dez. 2010.

MAGNINO, S. et al. Chlamydial infections in feral pigeons in Europe: Review of data and focus on public health implications. Veterinary Microbiology, v.135, p.54-67, 2009.

NATIONAL ASSOCIATION OF STATE PUBLIC HEALTH VETERINARIANS (NASPHV). Compendium of measures to control Chlamydophila psittaci infection among humans (Psittacosis) and pet birds (Avian Chlamydiosis). 2010. Acesso em: 02 dez. 2010. Online. Disponível em: <http:// www.nasphv.org/Documents/Psittacosis.pdf $>$.

SPEER, B.L. An update of avian Chlamydiosis. In: THE NORTH AMERICAN VETERINARY CONFERENCE, 1999, Orlando. Proceedings... Florida: Eastern States Veterinary Association, 1999. p.753-755.

RASO, T.F. et al. Chlamydophila psittaci in free-living Bluefronted Amazon parrots (Amazona aestiva) and Hyacinth macaws (Anodorhynchus hyacinthinus) in the Pantanal of Mato Grosso do Sul, Brazil. Veterinary Microbiology, v.117, p.235241, 2006. Disponível em: <http://www.sciencedirect.com/ science? ob=ArticleURL \& udi=B6TD 6-4KKNJ3F$1 \&$ user $=10$ \&_coverDate $=10 \% 2 \mathrm{~F} 31 \% 2 \mathrm{~F} 2006 \&$ rdoc $=1 \&$ fmt $=$ high 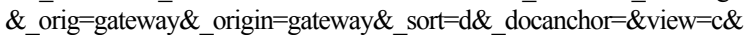

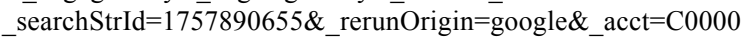
$50221 \&$ \& version $=1 \&$ \&urlVersion $=0 \&$ \& userid $=10 \& \mathrm{~m}$

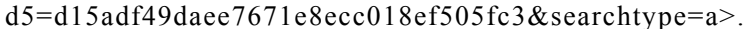
Acesso em: 22 mar. 2011. doi: 10.1016/j.vetmic.2006.06.025.

RASO, T.F. et al. Seroprevalence of Antibodies to Chlamydophila psittaci in zoo workers in Brazil. Zoonosis and Public Health, v.57, p.411-416, 2010. Disponível em: $<$ http://www.ncbi.nlm.nih.gov/pubmed/19538456>. Acesso em: 22 mar. 2011. doi: 10.1111/j.1863-2378.2009.01237.x.

VANROMPAY, D. Avian Chlamydial diagnosis. In: FUDGE, A.M. Laboratory medicine avian and exotic pets. Philadelphia: Saunders Company, 2000. Cap.12, p.99-110.

WORELL, A.B. Ramphastids. In: TULLY, T.N. et al. Handbook of avian medicine. 2ed. Oxford: Saunders Elsevier, 2009. Cap13, p.296-311. 